\title{
ASPEK BIOLOGI IKAN KENYAR Sarda orientalis FAMILI: SCOMBRIDAE DARI PERAIRAN SAMUDERA HINDIA
}

\author{
Wiwiet An Pralampita1), Siti Mardlijah"1), dan Umi Chodriyah"1) \\ 1) Peneliti pada Balai Riset Perikanan Laut, Muara Baru-Jakarta \\ Teregristrasi I tanggal: 1 Mei 2007; Diterima setelah perbaikan tanggal: 30 Agustus 2007; \\ Disetujui terbit tanggal: 29 September 2007
}

\begin{abstract}
ABSTRAK
Ikan kenyar (Sarda orientalis), merupakan komoditi perikanan yang tergolong ekonomis penting, selain sebagai komoditi ekspor juga untuk memenuhi permintaan pasar domestik, namun data dan informasi mengenai ikan tersebut sangat kurang, baik data statistik, maupun data biologi serta potensi dan distribusi kelimpahan. Penelitian tentang aspek biologi kenyar hasil tangkapan dari perairan Samudera Hindia telah dilakukan. Selama ini penelitian khusus mengenai ikan kenyar secara mendalam belum pernah dilakukan di Indonesia. Menurut hasil penghitungan nisbah kelamin, perbandingan kelamin ikan kenyar jantan dan betina berada dalam keadaan tidak seimbang, dan didapatkan betina lebih banyak. Kisaran ukuran panjang (FL) ikan kenyar dari Samudera Hindia 17,0 sampai dengan 69,0 cm. Hubungan panjang bobot ikan kenyar bersifat isometrik, dengan demikian pertambahan panjang ikan kenyar, seimbang dengan pertambahan bobot. Komposisi kenyar betina selama bulan pengamatan didominasi oleh kenyar dengan tingkat kematangan gonad III dan IV, yaitu lebih dari $50 \%$ jumlah, hampir di setiap bulan pengamatan.
\end{abstract}

KATAKUNCI: Sarda orientalis, panjang, bobot, nisbah kelamin, Samudera Hindia

ABSTRACT: Biology aspect of striped bonito Sarda orientalis family: Scombridae from Indian Ocean waters. By: Wiwiet An Pralampita, Siti Mardlijah, and Umi Chodriyah

\begin{abstract}
Striped bonito (Sarda orientalis) is fishery commodity which has important economic value. However, there is still lack of data and information about the fish, not only in statistic data but also biology data, potent, and distribution data. Research on biology aspect of striped bonito Sarda orientalis from Indian Ocean waters was conducted. Intensif research in striped bonito (Sarda orientalis) has not been done in Indonesia. Based on calculation of sex rate, ratio of male and female kenyar is very unbalance where the female is much more then the male. The length rate of striped bonito which is landed in Binuangeun, Pelabuhan Ratu, Cilacap, and Kedonganan vary from 17.0 until $69.0 \mathrm{~cm}$. The length weight corelation is isometric, indicate the more length the fish get, the more weight the fish get. The composition of in female striped bonito during the observation is dominated by the fish with gonate mature III and IV, which is more than $50 \%$ from all the fish that observed.
\end{abstract}

KEYWORDS: Sarda orientalis, length, weight, sex ratio, Indian Oceans

\section{PENDAHULUAN}

Ikan kenyar merupakan komoditi perikanan yang tergolong ekonomis penting. Ikan kenyar dimanfaatkan sebagai bahan baku industri pengalengan ikan. Ikan kenyar (Sarda spp.) adalah ikan pelagis yang termasuk dalam famili Scombridae. Dalam istilah nama umum termasuk dalam kelompok mackerel. Ikan kenyar menyebar di sepanjang Samudera Hindia, Atlantik, dan Pasifik, terutama di perairan tropik dan sub tropik (Collette \& Gibbs Jr, 1963; Maurice \& Burton, 1975). Di Indonesia, komoditas ikan tersebut bersama dengan ikan-ikan dari famili Scombridae lain menyebar di Samudera Hindia di Selatan Jawa sampai dengan Selatan Nusa Tenggara Barat (Pauly, 1996).
Ikan kenyar belum banyak dikenal secara luas karena hasil tangkapan yang didaratkan dari perairan Samudera Hindia belum banyak. Hasil tangkapan ikan kenyar bercampur dengan ikan tongkol, sehingga di dalam pencatatan digabung dengan ikan tongkol. Ada beberapa daerah misal Kedonganan (Bali) mengatakan tongkol kenyar, sementara di Binuangeun dan Pelabuhan Ratu dikenal dengan nama walangkekek.

Melihat bentuk ikan kenyar hampir mirip dengan cakalang tetapi kalau ikan kenyar mempunyai garisgaris di bagian atas tubuh, sedangkan ikan cakalang sebaliknya, garis-garis di bagian bawah (Gambar 1). 


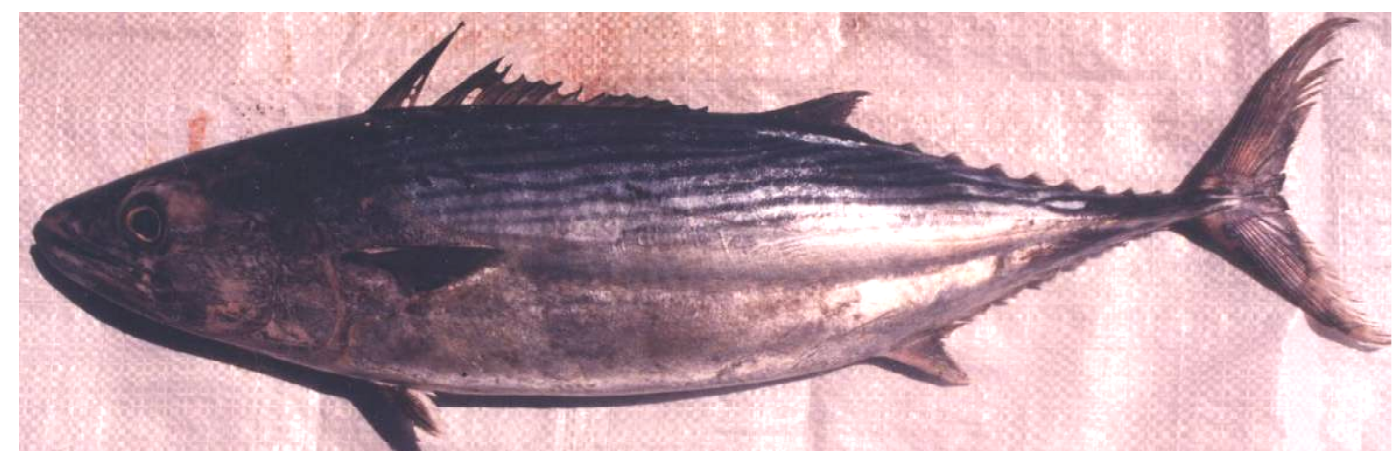

Gambar 1. Ikan kenyar (Sarda orientalis).

Figure 1. Striped bonito (Sarda orientalis).

Koleksi photo/Foto colection: Wiwiet An Pralampita

Berdasarkan pada hasil identifikasi jenis menurut baku acuan FAO diketahui bahwa spesies ikan kenyar yang terdapat di perairan Samudera Hindia adalah Sarda orientalis. Nama ikan kenyar dalam bahasa Inggris: Striped bonito, nama Perancis: Bonito oriental, dan nama Spanyol: Bonito mono.

Data dan informasi mengenai ikan tersebut sangat kurang, baik data statistik, maupun data biologi serta potensi dan distribusi kelimpahan. Hal ini, dikarenakan sampai dengan saat ini ikan kenyar merupakan hasil tangkapan sampingan (bycatch) dari upaya penangkapan tuna. Di samping itu penelitian khusus mengenai ikan kenyar secara mendalam belum pernah dilakukan di Indonesia. Penelitian ini diharapkan dapat menjadi input bagi pengembangan perikanan pelagis besar di perairan Samudera Hindia lebih lanjut atau sebagai salah satu bahan pertimbangan bagi langkah kebijakan dalam pemanfaatan dan pengelolaan.

\section{BAHAN DAN METODE}

Penelitian telah dilakukan pada tahun $2001 \mathrm{di}$ perairan Samudera Hindia. Pengambilan contoh ikan dilakukan di tempat-tempat pendaratan atau pelelangan ikan, yaitu Binuangeun, Pelabuhan Ratu, Cilacap, dan Kedonganan.

Data yang dikumpulkan meliputi data frekuensi panjang, bobot, dan parameter reproduksi. Contoh ikan diambil dari hasil tangkapan nelayan jaring dan pancing. Identifikasi jenis dilakukan dengan menggunakan sejumlah referensi, yakni Collette \& Nauen (1983); Tarp \& Kailola (1982); Bruin et al. (1994). Parameter- parameter biologi yang diukur adalah panjang cagak (FL) dalam $\mathrm{cm}$, bobot tubuh dalam gram, tingkat kematangan gonad ditentukan secara visual dan diameter telur. Ikan jantan dan betina dibedakan dengan membandingkan warna gonad.
Tiap-tiap jenis kelamin ikan dilihat tingkat kematangan gonad dengan berpedoman pada kriteria penentuan tingkat kematangan gonad menurut Schaefer \& Orange (1956), secara umum deskripsi dapat dilihat pada Lampiran, Tabel 1a (ikan betina) dan Tabel 1b (ikan jantan).

Contoh gonad diawetkan dalam larutan gilson, diameter telur diukur menggunakan mikroskop dengan pembesaran 100 kali baik untuk keperluan staging maupun validasi terhadap tingkat kematangan gonad. Gonado somatic indexs digunakan untuk mengatakan tingkat kematangan dan dihitung dengan rumus:

$$
\mathrm{GSI}=\mathrm{Wg} / \mathrm{W} .100 \%
$$

di mana:

$$
\begin{aligned}
& \mathrm{Wg}=\text { bobot gonad segar } \\
& \mathrm{W}=\text { bobot tubuh ikan }
\end{aligned}
$$

Analisis data untuk sebaran frekuensi panjang ikan dilakukan dengan mengelompokkan panjang (FL) ke dalam kelas dengan interval $5,0 \mathrm{~cm}$ dan hubungan panjang bobot dipakai formula:

$$
\mathrm{W}=\mathrm{a} \mathrm{L}^{\mathrm{b}}
$$

di mana:

$$
\begin{aligned}
\mathrm{W} & =\text { bobot ikan }(\mathrm{g}) \\
\mathrm{L} & =\text { panjang total ikan }(\mathrm{cm}) \\
\mathrm{a} \text { dan } \mathrm{b}= & \text { konstanta } \\
& \text { Sumber/Sources: Pauly (1980) }
\end{aligned}
$$

Untuk pengujian perbandingan ikan kenyar jantan dan betina dilakukan dengan uji Chi Kuadrat (Sugiyono, 2004), dengan rumus:

$$
X^{2}=\Sigma\left(f_{0}-f_{h}\right)^{2} / f_{n}
$$


di mana:

$X^{2}=$ Chi kuadrat

$\mathrm{f}_{\mathrm{o}}=$ frekuensi yang diobservasi

$\mathrm{f}_{\mathrm{h}}=$ frekuensi yang diharapkan

\section{HASIL DAN BAHASAN}

\section{Nisbah Kelamin}

Definisi dari nisbah kelamin adalah suatu angka yang menunjukkan perbandingan jumlah individu jantan dengan betina dalam suatu populasi. Secara alamiah, menurut Bal \& Rao (1984), di suatu perairan yang normal diperkirakan perbandingan betina:jantan adalah 1:1. Dari pengamatan terhadap 225 ekor ikan kenyar diperoleh hasil 95 ekor jantan dan 130 ekor betina. Sebaran perbandingan jumlah ikan kenyar

Tabel 2. Nisbah kelamin ikan kenyar (Sarda orientalis) bulanan dari Samudera Hindia Table 2. Monthly sex ratio of striped bonito (Sarda orientalis) from Samudera Hindia

\begin{tabular}{lccccc}
\hline \multicolumn{1}{c}{ Bulan/Month } & April/April & Mei/May & Agustus/August & September/September & Total/Total \\
\hline Seks ratio/ & $1,0: 0,5$ & $1,0: 0,5$ & $1,0: 1,5$ & $1,0: 0,9$ & $1,0: 0,8$ \\
Sex ratio $\left(+:{ }^{-1}\right.$ ) & 57 & 80 & 58 & 30 & 225 \\
n (ekor) & & & & &
\end{tabular}

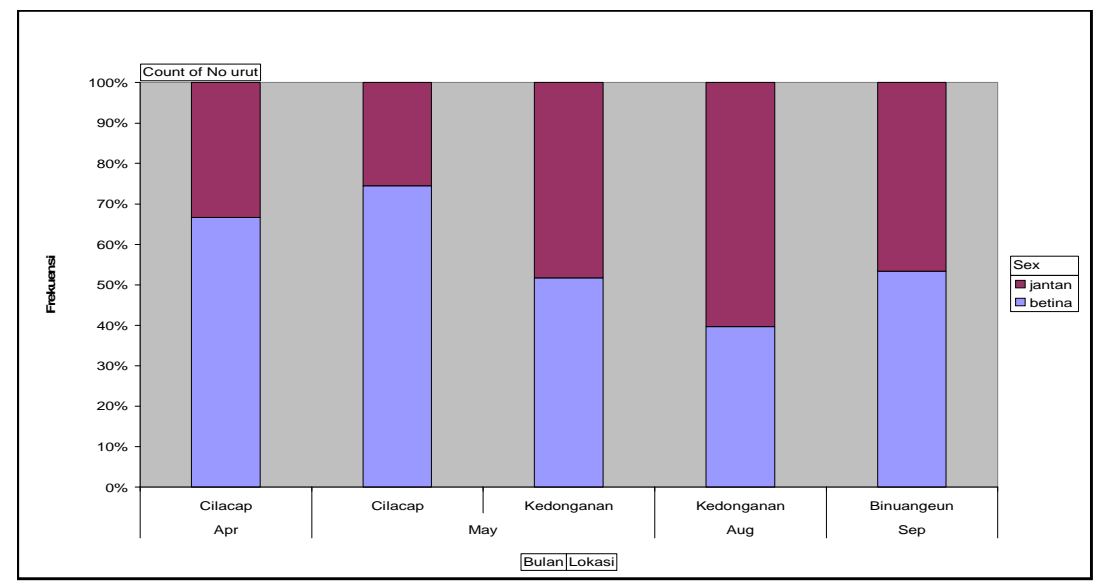

Gambar 2. Komposisi jumlah kenyar (S. orientalis), jantan dan betina hasil tangkapan dari Samudera Hindia pada lokasi dan bulan penelitian.

Figure 2. Composition of male and female striped bonito (S. orientalis) caught in Indian Ocean based on location and month.

yang berkelamin betina dan jantan setiap bulan pengamatan dapat dilihat pada Tabel 2 dan Gambar 2.

Apabila dilihat secara bulanan, (bulan April sampai dengan September) di tiap lokasi penelitian, terlihat perbandingan ikan kenyar betina dan jantan bervariasi, sering kali jumlah ikan kenyar betina lebih banyak dari jumlah ikan kenyar jantan terkecuali pada bulan Agustus. Analisis selanjutnya dari Tabel 2, terlihat perbandingan keseluruhan ikan kenyar betina dan jantan 1,0:0,8 (130:95 ekor). Analisis Chi kuadratyang menunjukkan hasil berbeda nyata $\left\{X^{2}\right.$ hitung $=14,548$; $\mathrm{X}^{2}$ tabel $_{(0,05)}=9,488 ; \mathrm{X}^{2}$ tabel $\left._{(0,01)}=13,277\right\}$ yang berarti perbandingan kelamin antara ikan kenyar betina dan jantan tidak seimbang. Menurut Bal \& Rao (1984), perbandingan yang tidak seimbang antara jantan dan betina ada hubungan dengan tabiat makan, memijah, atau migrasi dari tiap jenis ikan. Selaras dengan pernyataan Wahyuono et al. dalam Rohy (2001), bahwa apabila betina dan jantan seimbang atau betina lebih banyak dapat diartikan bahwa populasi tersebut ideal untuk mempertahankan kelestarian, sebaliknya apabila jantan lebih banyak dari betina dapat diartikan bahwa populasi tersebut tidak ideal untuk mempertahankan kelestarian atau cenderung punah. Dengan demikian, kesinambungan populasi ikan kenyar di perairan Samudera Hindia berjalan dengan baik.

\section{Ukuran Kenyar yang Tertangkap}

Ukuran maksimum yang pernah ditemukan adalah $80 \mathrm{~cm}$ dan pada umumnya kisaran ukuran yang tertangkap 30 sampai dengan $50 \mathrm{~cm}$ (FAO, 1974). Ukuran ikan kenyar yang didapat selama penelitian ada pada Tabel 3. 
Tabel 3. Kisaran panjang (FL) ikan kenyar (S. orientalis) bulanan yang tertangkap di Samudera Hindia Table 3. $\quad$ Range of length (FL) of striped bonito (S. orientalis) caught in Indian Ocean

\begin{tabular}{lccccc}
\hline & April/April & Mei/May & Agustus/August & September/September & Oktober/October \\
\hline Kisaran/ & $34,2-64,2$ & $32,9-69,0$ & $38,0-69,0$ & $17,0-65,1$ & $24,0-34,5$ \\
$\begin{array}{l}\text { Range FL (cm) } \\
\text { Rata-rata/ }\end{array}$ & 52,3 & 52,7 & 58,0 & 40,9 & 26,9 \\
$\begin{array}{l}\text { Average (cm) } \\
\text { Modus/ }\end{array}$ & 52,5 & 61,5 & 60,5 & 25,5 & 27,5 \\
Median (cm) & 57 & 103 & 196 & 137 & 75 \\
\hline n (ekor) & & & & &
\end{tabular}

\section{Gambar 3.}

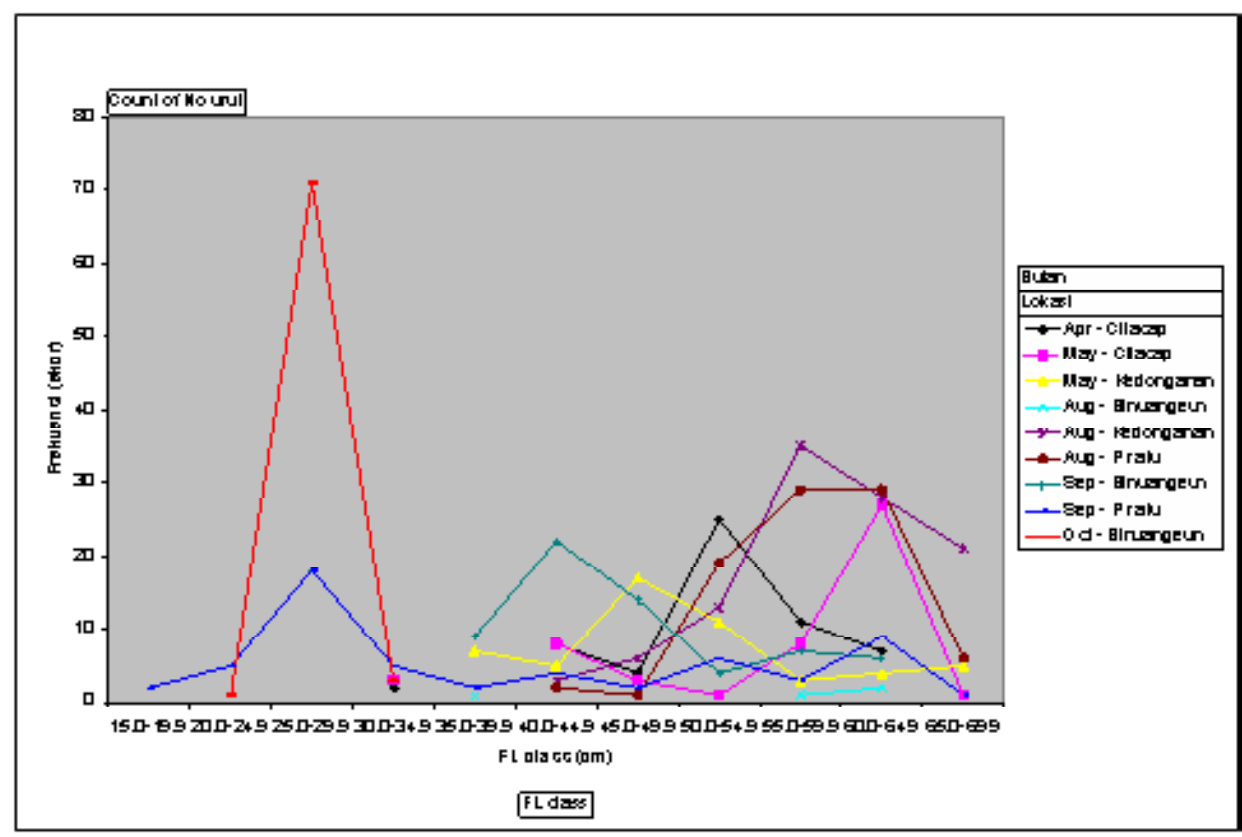

Figure 3. Fluctuation of body length striped bonito (S. orientalis) caught in Indian Ocean.

Kisaran ukuran panjang (FL) ikan kenyar selama penelitian 17,0 sampai dengan $69,0 \mathrm{~cm}$ dengan modus terendah $25,5 \mathrm{~cm}$ yaitu pada bulan September dan modus tertinggi yaitu $61,5 \mathrm{~cm}$ pada bulan Mei.
Dibandingkan dengan ukuran yang ditemukan oleh FAO pada tahun 1974, kisaran ukuran panjang ikan kenyar hasil tangkapan dari Samudera Hindia lebih luas.

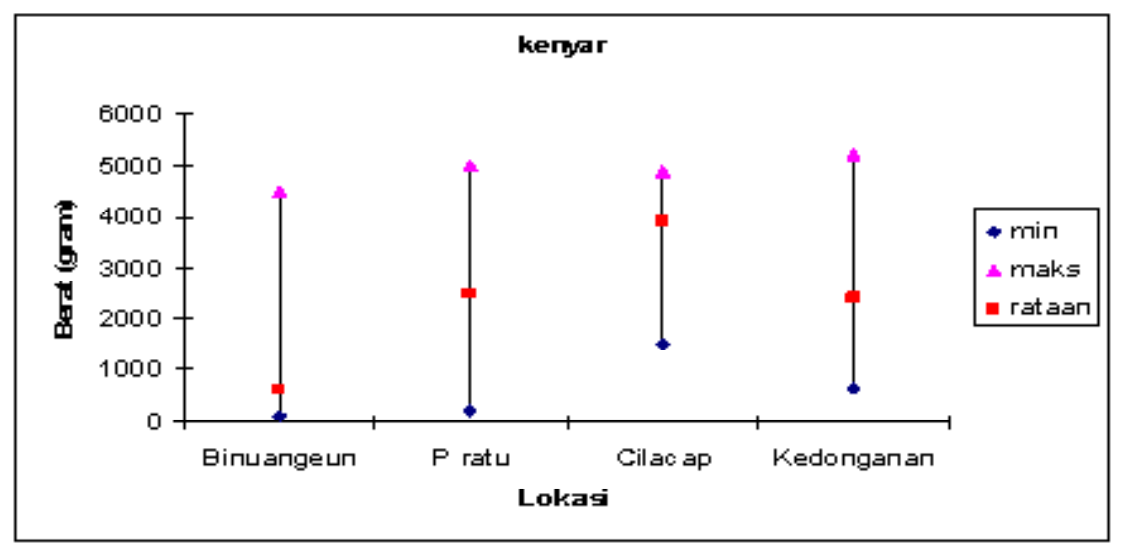

Gambar 4. Ukuran bobot kenyar ikan kenyar (S. Orientalis) di tiap lokasi penelitian, hasil tangkapan dari Samudera Hindia.

Figure 4. Weights of striped bonito (S. Orientalis) caught in every research location, cauht in Indian Ocean. 
Tabel 4. Parameter dari hubungan panjang bobot $\left(\mathrm{W}=\mathrm{a} \mathrm{L}^{\mathrm{b}}\right)$ ikan kenyar (S. orientalis) yang di dapat dari Samudera Hindia

Table 4. Parameter of the relationship $\left(W=a L^{b}\right)$ of striped bonito (S. orientalis) collected from Indian Ocean

\begin{tabular}{|c|c|c|c|c|c|c|c|c|}
\hline \multirow{2}{*}{ Bulan/Month } & \multicolumn{2}{|c|}{$\begin{array}{c}\text { Panjang/Length } \\
\text { (cm) }\end{array}$} & \multicolumn{2}{|c|}{$\begin{array}{c}\text { Bobot/ Weight } \\
\text { (g) }\end{array}$} & \multirow{2}{*}{$\begin{array}{c}n \\
\text { (ekor) }\end{array}$} & \multicolumn{2}{|c|}{ Parameter/Parameter } & \multirow{2}{*}{ r2 } \\
\hline & Min & Maks & Min & Maks & & $a$ & b & \\
\hline MeiMay & 32,9 & 69 & 650 & 4.900 & 103 & 0,1987 & 2,3938 & 0,6319 \\
\hline AgustusAugust & 38 & 69 & 500 & 5.200 & 196 & 0,0043 & 3,2752 & 0,6878 \\
\hline SeptemberSeptember & 17 & 65,1 & 100 & 4.500 & 137 & 0,0074 & 3,0820 & 0,8005 \\
\hline
\end{tabular}

Ukuran panjang ikan kenyar sangat berfluktuasi setiap bulan (Gambar 3). Pada bulan April ukuran ikan banyak didapat pada kisaran panjang 40,0 sampai dengan $64,9 \mathrm{~cm}$ dengan modus pada panjang 52,5 $\mathrm{cm}$, bulan Mei ikan banyak di dapat pada kisaran ukuran 30,0 sampai dengan $69,9 \mathrm{~cm}$ dengan 2 modus yaitu 46,5 dan $61,5 \mathrm{~cm}$. Pada bulan Agustus ukuran ikan banyak di dapat pada kisaran 35,0 sampai dengan $69,9 \mathrm{~cm}$ dengan modus $60,5 \mathrm{~cm}$, bulan September pada kisaran panjang 15,0 sampai dengan $69,9 \mathrm{~cm}$ dengan 3 modus yaitu pada kelas panjang 25,$5 ; 42,5$; dan $62,5 \mathrm{~cm}$. Pada bulan Oktober panjang ikan kenyar di dapat pada kisaran ukuran 20,0 sampai dengan $34,9 \mathrm{~cm}$ dengan modus pada panjang $27,5 \mathrm{~cm}$. Kisaran panjang paling lebar di dapat pada bulan September, mulai dari ukuran 17,0 sampai dengan $65,1 \mathrm{~cm}$ (Tabel 3 ). Modus tertinggi yaitu $61,5 \mathrm{~cm}$ pada bulan Mei.

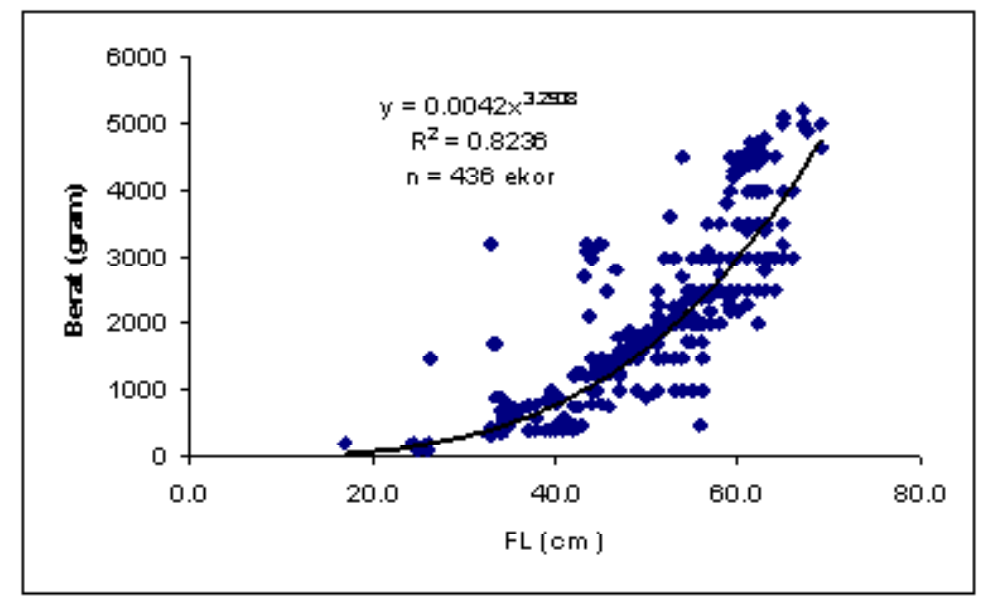

Gambar 5. Hubungan panjang bobot ikan kenyar (S. orientalis) yang tertangkap di Samudera Hindia.

Figure 5. Length weight relationship of striped bonito (S. orientalis) caught in Indian Ocean.

Tabel 5. Kisaran panjang (FL) dan nilai gonad somatik indeks kenyar (S. orientalis) berdasarkan pada tingkat kematangan gonad hasil tangkapan dari Samudera Hindia

Table 5. Range of length (FL) and value of gonad somatic indeks by maturity of femalestriped bonito (S. Orientalis) caught in Indian ocean

\begin{tabular}{|c|c|c|c|c|c|c|}
\hline \multirow[b]{2}{*}{ TKG (P) } & \multicolumn{2}{|c|}{$\mathrm{FL}(\mathrm{cm})$} & \multicolumn{2}{|c|}{ GSI } & \multicolumn{2}{|c|}{$\begin{array}{l}\text { Diameter telur/ } \\
\text { Egg diameter }(\mu)\end{array}$} \\
\hline & $\begin{array}{c}\text { Kisaran/ } \\
\text { Range }\end{array}$ & $\begin{array}{c}\text { Rata-rata/ } \\
\text { Mean }\end{array}$ & $\begin{array}{c}\text { Kisaran/ } \\
\text { Range }\end{array}$ & $\begin{array}{c}\text { Rata-rata/ } \\
\text { Mean }\end{array}$ & $\begin{array}{l}\text { Kisaran/ } \\
\text { Range }\end{array}$ & $\begin{array}{c}\text { Rata-rata/ } \\
\text { Mean }\end{array}$ \\
\hline II & $33,4-61,1$ & 47,9 & & & & \\
\hline III & $32,9-64,2$ & 53,3 & $2,9-12,4$ & 5,7 & $206,2-1.443,3$ & 768,9 \\
\hline IV & $39,0-69,0$ & 53,8 & $2,1-14,5$ & 5,6 & $206,2-1.546,4$ & 780,0 \\
\hline \multirow{2}{*}{ TKG $\left({ }^{\lambda}\right)$} & \multicolumn{3}{|c|}{$\mathrm{FL}(\mathbf{c m})$} & \multicolumn{3}{|c|}{ GSI } \\
\hline & & & Rata-rata/Mean & \multicolumn{2}{|c|}{ Kisaran/Range } & Rata-rata/Mean \\
\hline II & \multicolumn{2}{|c|}{$37,0-60,0$} & 45,6 & \multicolumn{2}{|c|}{ 0,3-3,8 } & 2,1 \\
\hline III & \multicolumn{2}{|c|}{$36,0-62,0$} & 48,4 & & & 2,9 \\
\hline IV & \multicolumn{2}{|c|}{$45,0-61,0$} & 54,6 & \multicolumn{2}{|c|}{$2,2-8,0$} & 4,5 \\
\hline
\end{tabular}


Ikan kenyar yang didaratkan di Binuangeun, Pelabuhan Ratu maupun Kedonganan mempunyai kisaran bobot yang luas, tetapi rata-rata bobot tertinggi, $3.922 \mathrm{~g}$ di dapat dari Cilacap. Bobot ikan kenyar terendah yaitu $100 \mathrm{~g}$ di dapat dari Binuangeun dan tertinggi yaitu $5.200 \mathrm{~g}$ di dapat dari Kedonganan (Gambar 4).

Untuk mengetahui bentuk hubungan panjang dengan bobot ikan kenyar, maka dihitung hubungan panjang bobot pada bulan Mei, Agustus, dan September seperti pada Tabel 4.

Hasil analisis regresi mendapatkan persamaan hubungan panjang bobot ikan kenyar $Y=0,0042 X^{3,2908}$ dengan nilai $R^{2}=0,8236$ dengan nilai $b=3,2908$ (Gambar 5). pada tingkat kematangan gonad IV 200 sampai dengan 1.600 mikron dengan modus 700 mikron (Gambar 6).

Komposisi ikan kenyar selama bulan pengamatan didominasi oleh ikan kenyar dengan tingkat kematangan gonad III dan IV, seperti terlihat pada Gambar 7 tersebut di bawah ini. Hal ini, patut dicermati tetapi belum dapat disimpulkan bahwa populasi ikan kenyar sudah terancam.

Kenyar dengan tingkat kematangan gonad II, III, dan IV pada bulan April di Cilacap, bulan Mei di Cilacap dan Kedonganan, bulan Agustus di Kedonganan, dan bulan September di Binuangeun. Komposisi kenyar selama bulan pengamatan didominasi oleh ikan kenyar dengan tingkat kematangan gonad III dan IV, seperti terlihat pada Gambar 7.
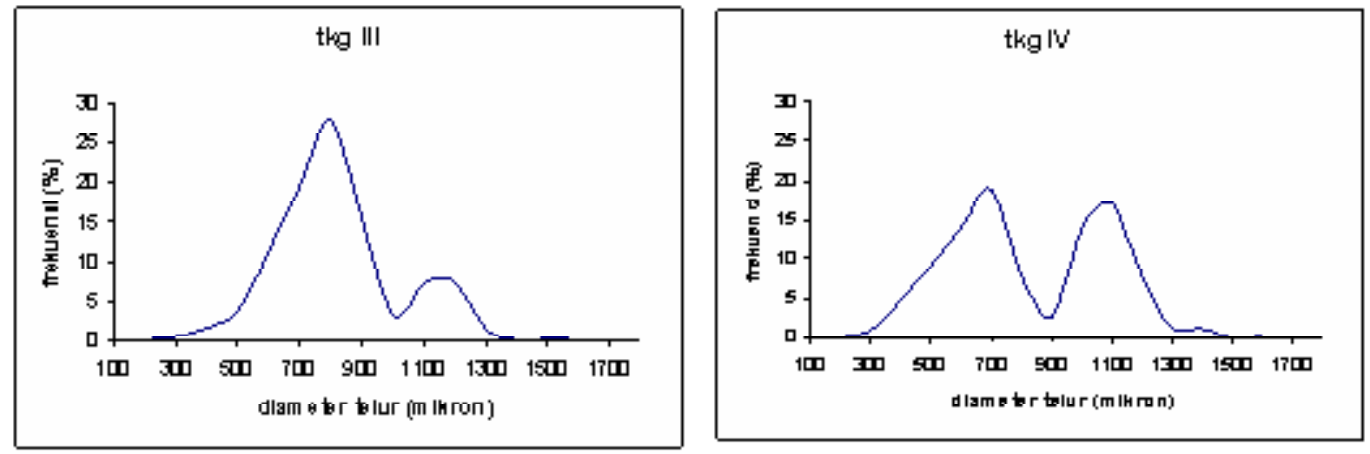

Gambar 6. Frekuensi (\%) diameter telur berdasarkan pada kematangan gonad ikan kenyar (S. orientalis) betina.

Figure 6. Frequency (\%) of egg diameter of ova based on gonad maturity of female striped bonito (S. orientalis).

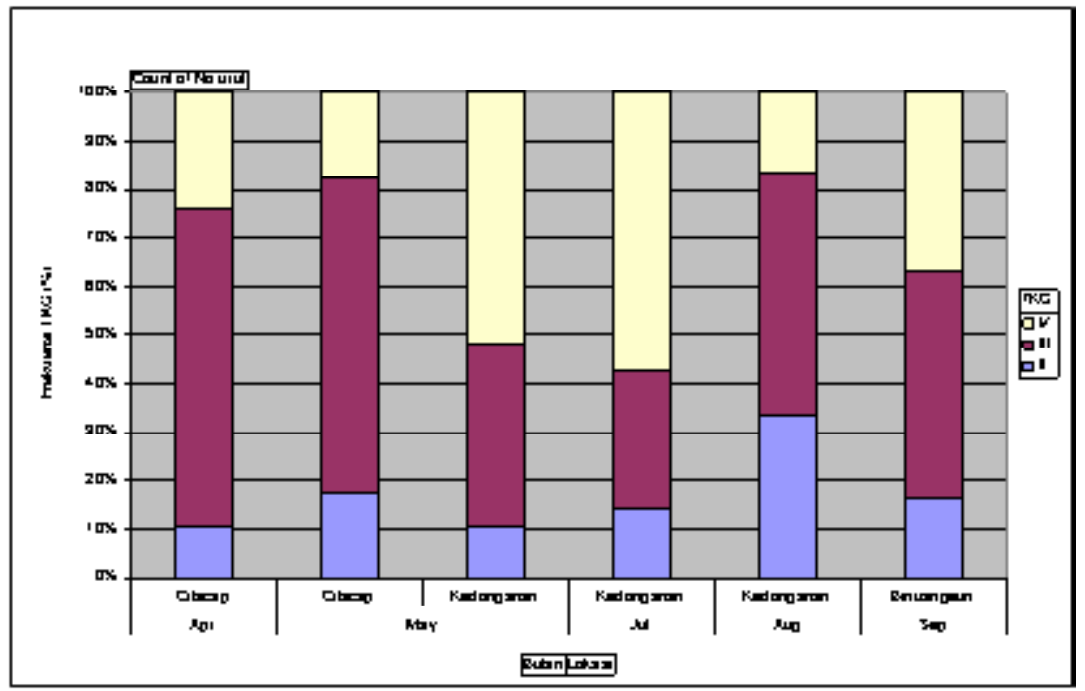

Gambar 7. Proporsi tingkat kematangan gonad kenyar (S. orientalis) berdasarkan bulan dan lokasi penelitian.

Figure 7. Proportion of gonad maturity of striped bonito (S. orientalis) based onmonth and location. 
Kisaran nilai gonad somatik indeks terluas pada bulan Juli yaitu 2,1 sampai dengan 14,5 dan terendah pada bulan Agustus yaitu 3,8 sampai dengan 9,1. Rata-rata nilai gonad somatik indeks tertinggi pada bulan Juli yaitu 7,4 (Gambar 8).

Kenyar dengan tingkat kematangan gonad II, III, dan IV didapat bersamaan pada bulan Mei, Juli, dan Agustus di Kedonganan dan September di Binuangeun (Gambar 9). Pada tingkat kematangan gonad II, mempunyai nilai gonad somatik indeks berkisar antara 0,3 sampai dengan 3,8. Kenyar degan tingkat kematangan gonad III mempunyai nilai gonad somatik indeks berkisar antara 0,8 sampai dengan 12,4. Kenyar degan tingkat kematangan gonad IV mempunyai nilai gonad somatik indeks berkisar antara 2,1 sampai dengan 14,5 . Nilai gonad somatik indeks terendah yaitu 0,3 didapatkan di Kedonganan pada bulan Mei dan gonad somatik indeks tertinggi yaitu 14,5 pada bulan Juli di Kedonganan.

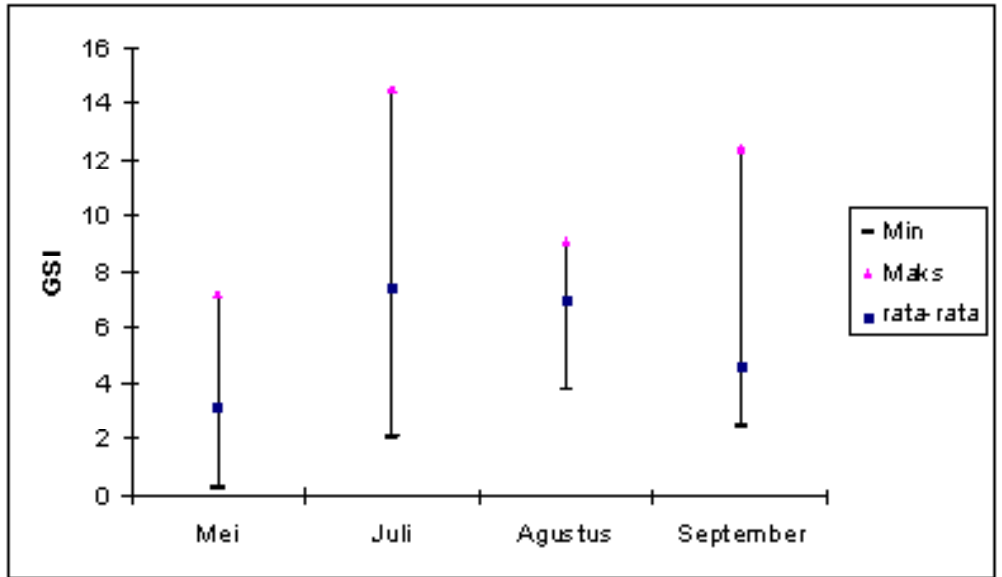

Gambar 8. $\quad$ Perkembangan nilai gonad somatik indeks kenyar (S. orientalis), hasil tangkapan dari Samudera Hindia.

Figure 8. $\quad$ The depelopment of gonad somatic index value of striped bonito (S. orientalis), caught in Indian Ocean.

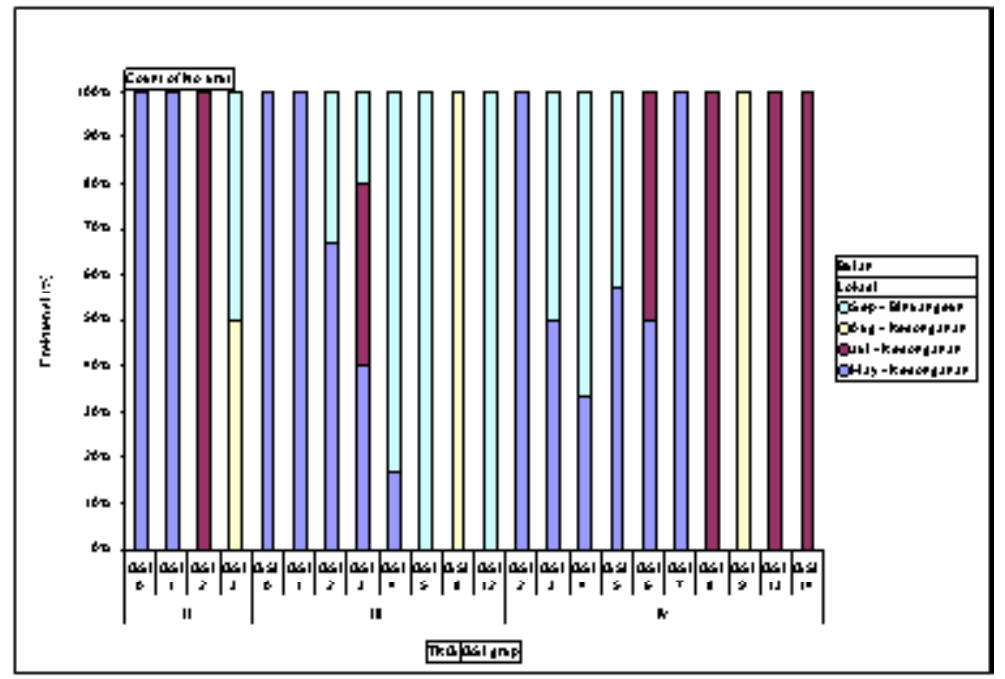

Gambar 9. Proporsi tingkat kematangan gonad ikan kenyar (S. orientalis) dan nilai gonad somatik indeks pada lokasi penelitian.

Figure 9. The proportion of gonad maturity of striped bonito (S. orientalis) and index somatic gonad in a location research.

\section{KESIMPULAN}

1. Ikan kenyar yang didaratkan dari Samudera Hindia ke lokasi penelitian adalah Sarda orientalis dari famili Scombridae.
2. Menurut hasil penghitungan nisbah kelamin, perbandingan kelamin ikan kenyar betina dan jantan berada dalam keadaan tidak seimbang dan didapatkan betina lebih banyak. Dengan demikian, 
diduga kesinambungan populasi ikan kenyar di perairan Samudera Hindia terjamin dengan baik.

3. Kisaran ukuran panjang ( $F L)$ ikan kenyar yang didaratkan di Binuangeun, Pelabuhan Ratu, Cilacap, dan Kedonganan 17,0 sampai dengan 69,0 $\mathrm{cm}$.

4. Hubungan panjang bobot ikan kenyar bersifat isometrik, dengan demikian pertambahan panjang ikan kenyar, seimbang dengan pertambahan bobot.

5. Komposisi kenyar selama bulan pengamatan didominasi oleh ikan kenyar dengan tingkat kematangan gonad III dan IV, yaitu lebih dari $50 \%$ jumlah, di setiap bulan pengamatan.

\section{PERSANTUNAN}

Kegiatan dari hasil riset biologi potensi dan distribusi kelimpahan cucut (Elasmobranchii), selengseng (Scomber australasicus), dan kenyar (Sarda spp.) di perairan Samudera Hindia, T.A. 2001, di Balai Riset Perikanan Laut, Muara Baru-Jakarta.

\section{DAFTAR PUSTAKA}

Bal, D. V. \& Rao K. V. 1984. Marine fisheries. Tata Mc. Graw-Hill Publishing Company Limited. New Delhi. p 5-24.

Bruin, G. H. P., B. C. Russell, \& A. Bogusch. 1994 The marine fishery resources of Sri Lanka. FAO. Rome. p 79-90.
Collette, B. B. \& Gibbs Jr. R. H. 1963. Preliminary field guide to the mackerel and tuna like fishes of Indian Ocean. Smithsonian Institution. 30 pp.

Collette, B. B. \& C. E. Nauen. 1983. FAO species catalogue. Vol.2. Scombrids of the World. An Annotated and Illustrated Catalogue of Tunas, Mackerels, Bonitos, and Related Species Known to Date. FAO Fish. Synop. (125). Vol.2. 137 p.

Maurice \& Burton R. 1975. Encyclopedia of fish. Octopus Books Limited. London. 253 pp.

Pauly, D. 1996. Biodiversity and the restrospective analysis of demersal trawl surveys: A programmatic approach. In D. Pauly \& P. Martosubroto (eds.) Baseline Studies of Biodiversity: The Fish Resources of Western Indonesia. ICLARM. Philippines. $312 \mathrm{p}$.

Rohy, I. C. 2001. Studi tentang aspek biologi dan aspek perikanan ikan cucut yang didaratkan di Pelabuhan Perikanan Pantai Prigi, Jawa Timur. Karya Ilmiah Praktek Akhir. Program Diploma 4. Sekolah Tinggi Perikanan. Jakarta. 63 hal.

Schaefer, M. B. \& C. J. Orange. 1956. Studies on the sexual development and spawning of yellow fin tuna (Neothunnus macropterus) and skipjack (Katsuwonus pelamis) in three areas of the eastern Pasific Ocean by exanation of gonads. Bulietin Inter-Am. Tuna Comm. 1 (6). 281-349.

Sugiyono. 2004. Statistika untuk penelitian. Penerbit C. V. Alfabeta. Bandung. 306 hal.

Tarp, T. G. \& P. J. Kailola. 1982. Trawled fishes of southern Indonesia and northwestern Australia. ADAB-DGF-GTZ. Singapore. 406 p. 


\section{Lampiran/Apenddix}

Tabel 1a. Kriteria tingkat kematangan gonad ikan kenyar (S. orientalis) betina Table 1a. The criteria of maturity stage of female striped bonito (S. orientalis)

\begin{tabular}{|c|c|}
\hline Tingkat/Stage & Penampakkan gonad/Gonad performance \\
\hline 1S & $\begin{array}{l}\text { Dara (virgin) } \\
\text { Ovari sangat kecil seperti pita, berada di bawah tulang punggung. Tidak dapat dibedakan } \\
\text { jenis kelamin antara jantan dan betina dengan kaca pembesar (loupe). Ovari (indung } \\
\text { telur) transparan, tidak berwarna sampai dengan abu-abu. Diperkirakan ikan dara, belum } \\
\text { pernah matang kelamin. }\end{array}$ \\
\hline 1 & $\begin{array}{l}\text { Dara berkembang (immature) } \\
\text { Ovari memanjang dan ramping, jenis kelamin dapat ditentukan dengan kaca pembesar. } \\
\text { Ovari jernih berwarna abu-abu sampai dengan kemerah-merahan. Telur satu per satu } \\
\text { dapat dilihat dengan kaca pembesar. }\end{array}$ \\
\hline 2 & $\begin{array}{l}\text { Perkembangan I (early maturing) } \\
\text { Ovari membesar, tetapi telur tidak dapat dilihat dengan mata biasa seperti serbuk putih. } \\
\text { Ovari bentuk bulat telur, berwarna kemerah-merahan dengan pembuluh kapiler. Ovari } \\
\text { mengisi sekitar setengah ruang bawah. }\end{array}$ \\
\hline 3 & $\begin{array}{l}\text { Perkembangan II (late maturing) } \\
\text { Ovari membesar dan membengkak, telur dapat dilihat dengan mata biasa. Ovari } \\
\text { berwarna orange kemerah-merahan, telur jelas dapat dibedakan dan bentuk bulat telur. } \\
\text { Ovari mengisi } 2 / 3 \text { ruang bawah. }\end{array}$ \\
\hline 4 & $\begin{array}{l}\text { Bunting, matang (ripe) } \\
\text { Ovari sangat membesar, telur jernih, dan masak, mudah ke luar dari lumen ovari kalau } \\
\text { perut ikan ditekan. Ovari mengisi penuh ruang bawah. }\end{array}$ \\
\hline 5 & $\begin{array}{l}\text { Mijah (spawned) } \\
\text { Termasuk yang mijah sekarang (salin) dan mijah sebelum (post spawning). Ovari sangat } \\
\text { besar, dan lunak (karena mijah). Telur matang yang tertinggal dalam keadaan terhisap. } \\
\text { Telur berwarna jernih dan ada yang tertinggal dalam ovari. Telur akan ke luar dengan } \\
\text { sedikit tekanan pada perut. }\end{array}$ \\
\hline
\end{tabular}

Sumber/Sources: Schaefer \& Orange (1956)

Tabel 1b. Kriteria tingkat kematangan gonad ikan kenyar (S. orientalis) jantan

Table $1 \mathrm{~b}$. The criteria of maturity stage male striped bonito (S. orientalis)

\begin{tabular}{|c|c|}
\hline Tingkat/Stage & Penampakkan gonad/Gonad performance \\
\hline $1 S$ & $\begin{array}{l}\text { Jaka } \\
\text { Testis kecil seperti pita, kelamin tidak dapat dibedakan dengan kaca pembesar. }\end{array}$ \\
\hline 1 & $\begin{array}{l}\text { Jaka berkembang (immature) } \\
\text { Testis sangat halus, pipih seperti pita, tetapi jenis kelamin dapat dibedakan dengan kaca } \\
\text { pembesar. Sebagian sperma terdapat dalam saluran pusat. }\end{array}$ \\
\hline 2 & $\begin{array}{l}\text { Perkembangan (maturing) } \\
\text { Testis membesar, penampang melintang berbentuk segitiga, berwarna kemerah-merahan } \\
\text { dengan pembuluh kapiler. Sebagian sperma terdapat dalam saluran pusat. }\end{array}$ \\
\hline 3 & $\begin{array}{l}\text { Matang (ripe) } \\
\text { Testis membesar dan membengkak, sperma ke luar bebas melalui saluran testis, dapat } \\
\text { dilihat dengan mata biasa. }\end{array}$ \\
\hline 4 & $\begin{array}{l}\text { Salin (partly spent) } \\
\text { Testis sangat membesar, berwarna bintik-bintik merah, sperma dalam saluran pusat, } \\
\text { mudah ke luar kalau perut ditekan sedikit. }\end{array}$ \\
\hline 5 & $\begin{array}{l}\text { Pulih salin (spent) } \\
\text { Testis lunak, permukaan berwarna merah, suram. Sedikit atau tidak ada sama sekali } \\
\text { sperma dalam saluran pusat. }\end{array}$ \\
\hline
\end{tabular}

Sumber/Sources: Schaefer \& Orange (1956) 